\title{
Convivencia, Abrahamic Religions and Study Abroad in Spain
}

\author{
Mitc hell A. Mc Coy \\ Sally Holt \\ Belmont University
}

\begin{abstract}
:
As a point of departure for understanding the complexities of Spanish national and individual identities, it is incumbent that a student begin by investigating Spanish iterations of the three Abrahamic religions. This presupposition of religion's centrality in the pursuit of better informed understandings of the Spanish nation, people, history and culture has served as cornerstone in the construction of Belmont University's Maymester study abroad program in Spain and as lodestar in its evolution. This article will describe the genesis of the program, analyze curricular changes over time and offer critical reflection about why international study is the quintessential milieu for achieving the sought-after objective: understanding the role of religions and the concept of convivencia in the cultivation of Spanish identities.
\end{abstract}

\section{Introduction}

Though most often lauded for her accomplishments as a contemporary writer of fiction in the United States, Marilynne Robinson is also a prolific essayist composing protracted thought on a wide range of topics including that of religion. Opining on the religiosity of U.S. citizens in The Givenness of Things: Essays she writes, “...it is perhaps even truer of our society than of most that religion and public life are inextricably involved. Where most people are religious, where their values or at least their sense of identity are formed by Christian cultural influences, and where government is at least formally popular, it could hardly be otherwise" (92). One of the enduring legacies of this Christian cultural influence about which Robinson writes is a plenitude of religiously affiliated institutions of higher education.

Belmont University is just such an institution. In its mission statement it aspires to be, “...a student-centered Christian community providing an academically challenging education that empowers men and women of diverse backgrounds to engage and transform the world with disciplined intelligence, compassion, courage and faith" (belmont.edu/about/mission.html). Furthermore, the Belmont Experience: Learning for Life (BELL Core or general education curriculum) encourages interaction on a global scale. The learning goals section of the BELL Core webpage states the following:

General Education seeks to help students develop an understanding of the complex nature of the world and become responsibly engaged with that larger whole, including:

- Local, national, international, and global perspectives 
- Multiculturalism

- The consequences of individual decisions in an interdependent world (belmont.edu/bellcore/vision_purpose_value_goals.html)

With these aspirational statements in mind, we (Dr. Sally Holt and Dr. Mitch McCoy) met in the Spring of 2014 with the idea of inaugurating a study abroad trip to Spain that would offer students both a cross-listed Spanish/Humanities course and the BELL Core Junior Cornerstone Religion and Ethics course. While the cross-listed course could be taken for Spanish or Humanities credit, the Junior Cornerstone course would ideally introduce students to a specific disciplinary way of knowing outside the student's major. As fields of study, religion and Spain were naturally complimentary, and the concept of convivencia popularized by Spanish Historian Américo Castro served as the axis about which our courses would revolve. Two overriding objectives of the trip would be to introduce students to the complexities of medieval Iberian society where three Abrahamic religious faiths coexisted for eight centuries, and to reflect in class about the ways people negotiate their individual and collective identities within religiously pluralistic societies.

\section{Program Genesis}

As professors of religion and Spanish our combined interests include, among many other topics, religion, language, literature, culture, identity, ethics and an acute awareness of the religiously besotted history of Spain. Spain intrigued us for its many sacred religious spaces that attest to the influences of the convivencia, a period of relative tolerance and occasional cooperation among the three Abrahamic religious cultures up until the Catholic Queen Isabel and King Ferdinand expelled the Jews in the late fifteenth century and the Muslims in the early sixteenth century. Writing about the convivencia in A Vanished World: Muslims, Christians, and Jews in Medieval Spain, Chris Lowney admits that,

Coexistence was fragile; members of each faith group preferred to build their own homogeneous society than to forge a mixed one. Frequently enough, however, that choice was unavailable. In consequence, an eloquent interfaith dialogue was occurring all over Spain every day in countless ways, the pedestrian but rich dialogue of daily life where one learns to accommodate the customs and beliefs of another through myriad quotidian interactions while baking, laundering, buying, selling, sowing, and reaping. (207)

While Lowney's characterization may lean toward the idealized and possibly even utopic, walking in the footsteps of the medieval Iberians and seeing the places shaped by the interrelationships of Spain's religio-historical milieu could begin to help crystalize students' understandings about an unfamiliar part of the world and the people who inhabited it. Seeing places first hand could spur students to question the role religion plays in the formation of individual and collective identities. Where does hospitality fit? Is it possible to understand and appreciate a religious tradition without adopting it?

After proposing and garnering approval for the trip through the Study Abroad Office we worked closely with CEA Study Abroad to organize travel arrangements and classroom accommodations. In May 2015 we launched the first iteration of what has become an annual study abroad trip to Spain. "Belmont in Spain: World Religion and Identities" is a Maymester short-term study abroad program described on a dedicated page of Belmont's website as follows: 
"Visit cathedrals, mosques and synagogues of southern Spain in this study abroad program of about two weeks in May. Religion Junior Cornerstone and a Spanish/Humanities cross-listed course anchor this program and offer students a unique opportunity to experience the diverse religious histories and peoples of Spain" (www.belmont.edu/study-abroad/programs/europe/spain/seville/ index.html). Since its inception in May 2015, the number of student participants has grown from six the first year, to sixteen in both 2016 and 2017.

\section{Program Struc ture}

The program begins with a mandatory pre-departure orientation at which we offer students information about the places we will visit, announce pre-departure common reading articles, and specify that they may take either the "Ethics and World Religions" course, "Negotiating Identities: Literary Imagination and Historical Critiques of Early Modern Spain" course, or both. Prior to departure, they read strategically selected articles that introduce them to aspects of the places we will visit and then write reflective journal entries that are handed in before boarding the plane for Spain. An intensive week of travel makes the first half of the program experientially rich while the second week employs traditional half-day classroom meetings to give students time to recall and process what they have seen. Interactive dialogues in small and large group formats give us and students opportunities to reconsider the articles and draw connections between places and texts. Additional afternoon activities continue to bring tangible experiences to bear on the reading and classroom activities. The complimentary content of the two courses make for a seamless co-teaching classroom environment. As epilogue assignments due after the trip has ended, both courses include two, post-trip book reviews that encourage even deeper reflection upon the themes of religion and identity and ask students to critically evaluate the links between those themes.

\section{Religion, Course Outcomes, and Course Texts Defining Religion}

From the study abroad program's name, "Belmont in Spain: World Religion and Identities", the potential participant gleans that the two principle themes of religion and identity are inextricably linked. The quintessential idea is that religion plays a crucial role in shaping identity for human beings.

With each successive year of the study abroad program since its inception, it has been a struggle to define, to hone, and to offer students an acceptable definition for religion. Definitions of religion abound, and if there is one certainty, it is the difficulty of defining it. Since religion can be an all-encompassing, abstract concept, a definition is helpful and necessary for students to be able to develop better informed interpretations of assigned readings, to intelligently process visits to sacred spaces and to contribute to reflective, classroom discussions. Those with even a peripheral grasp of worldly, current events are mostly familiar with the perennial conflicts that often characterize interactions among Jews, Muslims, and Christians, but the role of Spain in the histories of the practicants of these three faiths is usually less understood if not completely unknown.

David Dark recently published Life's Too Short to Pretend You're Not Religious, an insightful book on religion that pretends to contextualize the current ethos in the U.S. toward religion. Ruminating on religion he writes: 
Let's talk about religion. In its root meaning, religion (from the Latin religare, to bind again, to bind back) is simply a tying together, a question of how we see fit to organize ourselves and our resources, a question, we might say, of how things have been tied together so far and of how they might be tied together differently, a binding, an unbinding and a binding again. As has always been the case, the organizing of selves and societies can go beautifully or badly or both, but the development of bonds - like the dissolution of bonds - is inescapable. With this in mind, I find it most helpful to define religion as follows: a religion is a controlling story, and there are at least as many as there are people...Like culture, it cuts to the core of what we're really doing and believing, of what values - we all have them - lurk behind our words and actions. (14-15)

Keeping this idea of religion defined as bonds to past, present, and future at the forefront, we worked to outline objectives for both the Ethics and World Religions and Negotiating Identities courses.

\section{Ethics and World Religions Course: Leaming Outcomes and "The Omament of the World"}

While students are not required to take both courses, a majority always matriculates in "Ethics and World Religions" to fulfill both the Junior Cornerstone BELL Core requirement and the final religion course requirement for the baccalaureate degree programs. Because the course satisfies two requirements, it is a popular choice among students in all study abroad programs at Belmont University.

University Junior Cornerstone course goals ask students to:

- Understand the relevance of a discipline by engaging in disciplinary-based research in order to address a current issue or problem in the field.

- Communicate results via a discipline-appropriate venue.

- Learn to work effectively within a group and to recognize the value of collaboration and the advantages of bringing together people with different backgrounds and perspectives to address a common issue.

- Further develop critical reasoning skills through working in collaboration with peers.

The specific goal associated with "Ethics and World Religions" is to consider an exploration of ethics and the concept of hospitality in the Abrahamic religions in a particular time and place, examining how adherents of these traditions perceived their religious identities and understood teachings of their traditions. The class focus on Judaism, Christianity and Islam in medieval Iberia and "Early Modern Spain" concentrates on the concept of convivencia which implies a harmonious living together as opposed to a toleration marked by tension. There is debate about whether or not a golden age of tolerance among Jews, Christians and Muslims existed in medieval Iberia and that debate is highlighted by the course.

Our study investigates the fragile and fruitful relationship that did exist, even though marred at times by intolerance and violence. The use of ethical frameworks and comparative-historical analysis seeks to help explain factors that allowed for this period of coexistence to occur and to help 
students investigate intercultural understandings of the other, as well as sacred texts in each religious tradition, where hospitality for the stranger is commanded. By delving into this study of the past, several significant pieces of learning hopefully occur.

First, students become familiar with the role that religion played in forming Spanish identities, both individual and collective. Second, students become acutely aware that specific cultural contexts and time periods shape religion in the moment. Thus, and thirdly, students grow in their understanding of their own identities, religious or otherwise, and how their own contexts inevitably shape how they understand themselves. For example, then, a Catholic student develops a clear picture of how some elements of her tradition may remain consistent over time and regardless of place, and how other aspects of religious identity are indeed very much determined by both time and place. Spanish and Catholic identities in the sixteenth and seventeenth centuries were not uniform of course, but clearly such individual and collective identities are quite removed from contemporary understandings of American Catholicism today, diverse in its own right.

By the conclusion of our study together, students should have a reasonable introductory knowledge of the Abrahamic religions. Further, students should be able to reflect on the role of religion in forming the ethos out of which arise moral commitments and perceptions of what is right and good. Finally, students should practice cooperation and collaboration as they work together in groups characterized by diversity, while studying this intriguing historical period in Spanish history known for its thought-provoking religious diversity.

\section{Menocal}

Maria Rosa Menocal's, Ornament of the World: How Muslims, Jews, and Christians Created a Culture of Tolerance in Medieval Spain, is the primary text utilized in the "Ethics and World Religions" course. In her postscript, Menocal references the violence of September 11, 2001, and the devastation that religious intolerance can wreak (282-283). Despite the disturbing nature of that tragedy, it resonates with student readers and helps them forge connections to Spain's turbulent history of interreligious relationship.

The history she recounts and the stories she tells draw our attention to the greatness that is possible when tolerance flourishes. Examples she offers often parallel the places we see and the historically significant figures our guides mention. Her descriptions of the art and architecture that envelop us attest to an inspirational, creative ethos wrought by a semblance of religious freedom. She also includes narratives referencing the intolerance that builds and eventually leads to the expulsion of Jews from Spain in 1492 and Muslims in the sixteenth century. Though her narrative is not without detractors, the book problematizes convivencia well, sparks interest in the study of Spain and serves as a good point for entry into the complexities involved.

\section{Negotiating Identities Spanish/Humanities Course: "The Abencerraje" and "Ozmín and Daraja"}

In general, we have discovered that fewer students enroll in the "Negotiating Identities" Spanish/Humanities cross-listed course. Nonetheless, the way we structure the classroom component for the week that we are in class exposes all students to some of the literary content of the cross-listed course. By design, we especially want students of Spanish who are usually more 
familiar with Spain, its history, culture, and people to intermix with their less informed classmates that have only joined the trip for the Junior Cornerstone credit.

The credit for Spanish is restricted to Spanish language students who can demonstrate presentational writing skills at the American Council on the Teaching of Foreign Languages (ACTFL) intermediate mid to advanced low level ("Can Do Statements" 4-5). Although pre-class readings are all in English and classroom discussion and activities are also conducted in English, the course offers Spanish students an opportunity to practice translingual negotiation. They prepare before class by writing in Spanish about their reading and then must distill those ideas back into English in the classroom with their classmates. By incorporating translingual activities for the student that seeks Spanish credit, the course follows Modern Language Association (MLA) recommendations outlined in "Foreign Languages and Higher Education: New Structures for a Changed World." The writers of this MLA report maintained in it that, "Advanced language training often seeks to replicate the competence of an educated native speaker, a goal that postadolescent learners rarely reach. The idea of translingual and transcultural competence, in contrast, places value on the ability to operate between languages" (Foreign Languages). The "Negotiating Identities" cross-listed course seeks to test and improve the translingual skills of the students who choose to take it for Spanish credit.

Students taking the course for humanities credit fulfill a BELL Core curricular requirement. The classroom dynamic is unique from a strictly Spanish or English course because it merges groups of students whose course selection would not normally bring them together.

Learning Objectives for the cross-listed "Negotiating Identities" course include the following:

- To observe contemporary Spanish people, places, customs and culture and appreciate links between the present and the past.

- To read, assimilate and explain what we mean when we speak of human identity individual, collective and in particular, the identities of Spaniards in Early Modern (sixteenth and seventeenth century) history and in contemporary Spain.

- To analyze how two sixteenth century fiction novellas idealized, invented and presented the relationship between different religious traditions

- To speak from an informed perspective about Spain's sixteenth-century historical milieu and relate important occurrences in Spain that contributed, and continue contributing, to shaping Spanish identities.

- To explain how religions (links to authorities and traditions from the past) played and do play a role in both individual and collective identities of Early Modern and contemporary Spaniards.

Through reading fictional representations of the interplay between Christian and Islamic characters, students are encouraged to consider how imagination plays a vital role in the conception of identity in contradistinction to the notion of a purely rational, historical account of the same. Writers of fiction may exercise liberty, explore possibilities, shape thought, and push boundaries of what is acceptable religious interaction among characters convicted by their faiths. Students are 
encouraged not only to see the liberty of fiction but to ponder how it would influence its readers' thoughts and actions in their communities. The power of wildly popular fictional texts demonstrating friendship between co-religionaries might have profound and enduring influence not only intrinsically in the reader's identity, but begin to also impact the collective identity as those readers retell and recount how friendship and hospitality might be possible. Additionally, it is possible to imagine how fiction might be employed to guide behaviors in a different direction, to proselytize, to influence political opinion or to appeal to both the rational and the emotional.

Sixteenth-century Spanish literary representations demonstrating interactions among coreligionaries is not always available in English. Fortuitously in 2014, just prior to the inaugural Maymester program for Belmont's World Religion and Identities, Barbara Fuchs et al. published an English version of "The Abencerraje" and "Ozmin and Daraja": Two Sixteenth-Century Novellas from Spain. Enormously popular literary works when first produced, they both exemplify how popular literary idealizations of interactions between Muslim and Christian communities could serve as ways of imagining the realities of co-religionaries.

Fuchs highlights in her introduction the concept of maurophilia, a fascination, and adoration among the Catholic conquerors not for the religion of Islam, but rather the material culture. "Christians greatly admired the elaborate Andalusi architecture, gardens, poetry, horsemanship, furnishings, and fashions they found when they conquered such important cities as Toledo (1085) and Seville (1248), and they soon incorporated them as their own, creating a Castilian culture with many shared elements" (4). Furthermore, Fuchs purports that "While the maurophile novellas may be idealizing in their focus on chivalry and exalted feeling, they also chart the vivid presence of the Andalusi heritage in quotidian Spanish culture" (3). The overlapping nature of religious practice and material culture stand out for the reader of Fuchs' version.

By the time students begin to engage the idealized literary texts of The Abencerraje and Ozmin and Daraja, they have already visited the cities of Toledo, Córdoba, Granada and Seville. The guided visits include stops at the ruins of the Casa de los Abencerraje in the Alhambra complex, and during the visit to the Summer Palace in the Generalife the guide narrates an account of the legend of the massacre of the Abencerraje family.

Aside from its critical introduction where Fuchs defines the concept of maurophilia, she also includes a section after the translated novellas entitled "Contexts" in which the reader learns about the Moorish Ballad tradition and enjoys selected sections of the chronicle account of the Civil Wars of Granada by Ginés Pérez de Hita as well as various Edicts and Official Documents. For the purposes of showing the interconnectedness of religious belief in sixteenth-century Spain, the need for political consensus, the everyday manifestations of folk ballads, manners of dress, celebrations of music and fictional representations of the relationship of Muslims and Christians, Fuchs' edition remains quintessential for the "Negotiating Identities" course.

\section{Common Artic le Writing Activities: Abrahamic Religions in Iberia}

After the inaugural year of the program, we discerned that pre-trip readings would foster the learning process and help students with little or no knowledge about Spain prepare for the visits. Taking into account the travel trajectory to Toledo, Córdoba, Granada and Seville we researched and 
selected articles that would offer expert observations about the interplay among Jewish, Muslim, and Christian people in the cities, places, and spaces we planned to visit. The selection process was arduous because there are abundant resources from which to choose. The combination of articles from journals and chapters from monographs are assigned for reading in both courses and made available to students in chronological folders online, via Dropbox.

Students read each article and then produce a one-page written reflection to this common article. We refer to the activity as the Common Article Writing Activities (CAWA). The purpose of each CAWA is to equip students with the ability to begin making connections between the reading and what is actually observed during visits to synagogues, cathedrals and mosques throughout the trip.

Students are given the following instruction about the value of CAWA in preparation for this work. These articles are intended to:

1. Help you begin thinking both about how we as humans define and negotiate identity (individual and collective) as well as how we understand and make sense of the impacts of three Abrahamic religions on identity.

2. Introduce you to Spanish historical, political and social contexts before setting foot in the country so that you'll be somewhat informed. We invite you to rigorously put forth effort to understand the common articles because being informed enriches your every experience in Spain, particularly when you live with a host family in Seville.

3. Get you writing to make sure you're dialoguing with the common articles individually.

This was an important and welcome change during our second and third years. Students are better able to appreciate the site visits and excited when they are able to intelligently answer the questions posed to them by our guides. Articles reinforced by site visits begin to take root in the imagination of the students. While we remain satisfied with some of the common articles, we continue to search for others that may be more pertinent to the sights we see. The articles and chapters are our primary tool for introducing students to the Iberian iterations of the three Abrahamic religions.

\section{Iberian Amalgam of Abrahamic Faiths \\ Sephardim}

Three distinct Jewish cultural traditions are observable over time. The Mizrahim are the first Jews of the Diaspora, those who never returned to Judea from the Babylonian exile of the sixthcentury BCE. The Jews that migrated to France and Germany became known as the Ashkenazim, and those who settled on the Iberian Peninsula (Portugal, Spain as well as parts of North Africa) became known as the Sephardim. Each of these groups experienced periods of prosperity and decline. The Sephardic Jews of Spain are responsible for some of the most creative developments within Judaism and also experienced some of the most severe persecution faced by the Jewish people (Felton 16).

The two common articles that bring the Sephardic Jews of Spain into focus are a chapter from Anton Felton's, Jewish Symbols and Secrets: A Fifteenth Century Spanish Carpet, and a chapter from After 
Expulsion: 1492 and the Making of Sephardic Jewry by Jonathan Ray. Felton's chapter "The Jews of Spain" helps introduce students to theories about Jewish settlement in Spain and also begins to introduce them to the names of places, people, and groups that one must be aware of if any significant understanding of the Sephardim is to be acquired.

As Ray suggests in After Expulsion, the identity of Sephardic Jews, “...to the extent it existed at all, was less an organic expression of a unified society than an external category used by the Jewish elite to describe some of the distinct intellectual traditions and religious customs of Iberian Jews" (13). The hybrid culture that surrounded the Jewish minority population was not conducive to developing a pervasive collective Jewish identity, and, according to Felton, the Sephardic Jew is always "in an alien land" (13). Existence as a minority and in diaspora (in exile) is an undeniable aspect of Jewish identity.

\section{Catholic Monarchy}

To understand Iberian Christian thought, word, and deed in late fifteenth-century Spain is to enter into a complex of Catholic religious orders whose goals and missions intertwined intimately with the monarchical political system. The learned, scholarly system in Spain as elsewhere in Europe was tightly connected to what traditionally was known as the Queen of the Sciences, Theology. It offered a moral philosophical structure that purported to guide the merged Castilian and Aragonese political institutions.

To concisely address issues that arise after Reconquest, we assign as a common article one by Maya Soifer. In "Beyond Convivencia: Critical Reflections on the Historiography of Interfaith Relations in Christian Spain", Soifer addresses convivencia, coexistencia, and conveniencia, three terms used by historiographers to characterize the complex interrelations between Jewish, Muslim and Christian co-religionaries. Soifer sympathizes with a nuanced approach to analyzing Iberian interfaith relations maintaining that, "...a growing number of historians try to modify the concept of convivencia or replace it with analytical categories that seem better equipped for describing the untidy realities of Jewish-Christian-Muslim coexistence in medieval Iberia” (23).

\section{Islam}

In The Ornament of the World, María Rosa Menocal writes of the influence of Bedouin Arabs on Islam as a religion, especially in its expansion across North Africa and ultimately into Iberia. Her claims are not unknown to scholars, but often are unknown or unfamiliar to students. Menocal writes:

Islam was nothing less than the return to the pristine monotheism of Abraham - abandoned or misunderstood by Jews and Christians alike, the revelations asserted, and unknown altogether to the benighted pagans of the desert. All this came forth not in Muhammad's own words but through his transmission of the direct language of God, his "Recitation"- the word Quran means "recitation" - of what God was revealing and dictating to him. (18-19)

The powerful wave of expansion that characterized Islam and its internal struggles moved rapidly from the Arabian Peninsula toward Iberia in the eighth century. While not focusing specifically on medieval Iberia as a time period, it is important for students to understand the monotheistic nature of Islam, the eight centuries of influence it brought to Iberia's Al Andalus and 
the lasting cultural legacy seen not only in the places we visit, but also in the unique ethnic mixture of people.

\section{Religions in Places and Spaces}

Traveling to and visiting the eclectic places and spaces where students can personally witness the architectural vestiges of three faiths is a central purpose for Belmont in Spain. The common article readings are assigned strategically to anticipate and introduce each city visited. We want students to distinguish between medieval Iberia, Al Andalus and the composite monarchy of the Catholic Queen Isabella and King Ferdinand that birthed the contemporary Spanish nation.

To get a sense for the creeds of the Abrahamic faiths and the rapid conversion of people across the Middle East, North Africa and the Iberian Peninsula that occurred after Muhammed the Prophet's death, we listen to an interview from On Being, a radio program by Krista Tippett. In an interview she conducted of the eminent historian of Christianity, Jaroslav Pelikan, he marveled at the rapidity of Islam's spread:

Whereas to be Jewish is to affirm every day, if you're observant, and with your dying breath, if you can, 'Hear, O Israel, the Lord is our God the Lord is one', the Shema, and that's really all the creed that Israel needs. So it's been possible to be Jewish now for these 3000 or whatever years without publishing four volumes of creedal texts. There is no God but Allah and Mohammed is his prophet is enough of a creed to animate the most rapid expansion of a religion in the history of humanity from the death of the prophet in 632 to 732 in Gaul at the Battle of Tours, Islam managed to spread from the Arabian Peninsula south and all the way across the Northern Coast of Africa to Gibraltar and into Spain and on into France in a hundred years with this one little creed, and Christianity sprouts them at will right and left. (Tippett; Soundcloud 04:22-05:37)

The admixture of Abrahamic faiths and their centrality in forging changes in Iberian culture was itself rooted in a fundamental struggle to reconcile reason and theology. As María Rosa Menocal describes it:

But one of the fundamental stories of the medieval West, one where the Latin Christian world and the Arabic Muslim and Arabic Jewish universes are felicitously intertwined, is of the noble effort to produce and maintain a first-rate culture, one that could hold together, at the same time and in the same place, the two contradictory modes of thought and belief. (204-205)

Aiming to contextualize the Islamic, Jewish and Christian presence in Spain is carried out during our program by visiting Toledo and the Andalusian cities of Córdoba, Granada and Seville.

Despite the razing of many mosques or appropriation of the space by Catholic conquerors and superimposition of Catholic symbols during the long history of reconquest, there are numerous places in modern Andalusia where vestiges of Jewish and Islamic presence are visible. Since seeing is such an integral part of believing and understanding, visits to Jewish synagogues and Islamic mosques achieve the objective of demonstrating how Islamic art, architecture and engineering influenced lives and landscape alike. 


\section{Madrid - Toledo - Córdoba}

After an international flight, program orientation and one night of difficult sleep in Madrid, we depart early in the day for the city of Toledo. The city of Toledo stands in marked contrast to the frenetic pace of Madrid. It is the first encounter where students feel extracted from contemporary history and thrust into the past. It is a history that engages each of their senses and brings to life the pre-trip readings. As the bus winds its way up the hill opposite the city, unsuspecting students chat and listen to a guide give some background about Toledo, referring to its Roman roots. They are unprepared for the absolutely breathtaking view of the walled city, surrounded on three sides by the Tagus River.

After stopping to take in the view of Toledo from a distance, we travel into the city. We walk first to the Iglesia de Santa María la Blanca, also known as Sinagoga Santa María la Blanca. This Catholic structure with Christian altar, Islamic horseshoe arches, walls decorated with Arabic script in stucco and a lone Star of David hidden in the Arabic decoration attest to the once religious hybridity of Toledo.

While not a large city, Toledo has immense importance as a symbol of multicultural society and as an important religious center of medieval Iberia. The history of the period and of the country as a whole may be overwhelming, but the city serves as a starting point for students to begin piecing together the people and places that distinguish medieval Iberia and Early Modern Spain. The Visigoths of Toledo, for instance, are remembered for holding a series of church councils to debate issues such as Arianism, and their Christian rule came to an end in Toledo in 711 when Tariq ibn Ziyad gained control of the city. This began a period of Muslim rule that would last until 1085 (Menocal 194).

Under Muslim rule, convivencia appears to have been more of a possibility than it had been under the Visigoths, who had alienated Jews by enacting laws that forbade them from marrying Christians and that outlawed observance of Jewish holy days (Lowney 58). Even under Muslim rule though, this co-existence of Jews, Christians and Muslims was largely a matter of convenience in which people of different faiths lived, worked, and interacted together, sometimes peacefully, sometimes not, for reasons that had much to do with financial and political gain. As a result of these mutually beneficial relationships, many elements of culture were appropriated and adopted among the three groups, forming a unique shared heritage that is reflected in the art and architecture of the period (Charbonneau 1). This history is observable in the religious art and architecture of Toledo. Being there makes students acutely more aware of the purpose of our study in Spain.

The following day, we travel by high-speed train to Córdoba, where there are reminders of a tolerant past where Jews, Christians and Muslims lived together in a period of productivity, but the reality of this coexistence is quite complicated and not always pleasant. Our primary reason for a stop in Córdoba is to visit the Mosque-Cathedral, also known as the Great Mosque of Córdoba or the mezquita. We also tour the Jewish Quarter, where we see a statue of Maimonides, the gifted twelfth-century Jewish scholar and physician.

As Menocal notes in The Ornament of the World, Maimonides was born in Córdoba in 1135 during the end of Almoravid rule (208). His life marks a period of change in the history of tolerance in Córdoba, as he and his family were forced to flee from the city and from Spain because 
of increasing religious persecution of the Jewish population by Muslim rulers that no longer adopted the policies of predecessors that had allowed for cooperation and coexistence (Lowney 146).

When visiting the Mosque-Cathedral in Córdoba, a visitor senses this move from tolerance to intolerance in the architecture, though at this point the story has changed to one that involves Muslims and their Christian conquerors. Within the mosque, an imposing cathedral was begun in 1236 and later significantly expanded in the sixteenth century, its minaret converted to a bell tower. Dodds writes that, "the emperor Charles V, who had originally supported the canons in their petition to build within the mosque, is recorded to have remarked upon seeing the new cathedral: 'You have taken something unique and turned it into something mundane"' (25). Even today, the site remains a place that sparks controversy and debate.

\section{Granada}

Having seen parts of Toledo and Córdoba, students' next exposure to Christian and Islamic spaces include the Cathedral, Royal Chapel, Hieronymite Monastery, and the fortress city of the Alhambra in Granada. For two full days, we walk a great deal through Granada and the Alhambra takes center stage high on a hill above the modern city center; it impresses even a modern day observer. A legacy of Islamic engineering and ingenuity that harnessed water from far away using natural gravity to bring it to the fortress and city complex that served both as dwelling place and symbol of power.

The Islamic power structure ruled from the site and lived in a luxurious natural setting employing the cooler temperatures of the higher altitude of the Summer Palace to retreat from the heat. Water in bubbling fountains is ubiquitous for the ablutions required by Islamic faith, and serves also to reflect the magnificence of the architectural accomplishments.

Designed with customary patio style of Arabic structures in North Africa, the highlight of the Alhambra complex is a courtyard that contains a sculpted fountain wrought by Jewish subjects. The twelve lions that encircle the center fountain served as a constant reminder of the twelve tribes of Judah so central to Judaic co-religionaries in the midst of a majority Islamic population. It also stands as a visual legacy of the, at times, hospitable links between peoples of contrary religious traditions.

“The Alhambra an Introduction" by Darío Cabanelas Rodríguez is assigned for reading by students in advance of the visit. Its content expounds upon the layered nature of the complex's history and the successive construction projects that highlighted its centuries long, ongoing expansion. His subdivided article includes sections on the Nasrid Alhambra and the Christian Alhambra demonstrating the hybridity of the spaces and the concretion of Islamic and Christian architectural and decorative influences. Rodríguez points out that, "The Alhambra is the only palace that has remained from the Muslim Middle Ages nearly intact and relatively well preserved. It survived because the entire complex became part of the royal patrimony; the King and Queen declared it a Casa Royal, a royal residence, and took it upon themselves to preserve its fragile buildings" (131-132). The strategic symbolism of appropriating such an important Islamic space for Christendom was not lost on the Reyes Católicos nor their subjects after subduing the ruling Muslim Nasrids and the Islamic majority population in January 1492. 
The monument's importance for understanding the height and magnificence of Islamic power in Spain cannot be underestimated. It tangibly contextualizes the history of Granada and its key role in the unification and reconquest process led by Isabella and Ferdinand.

\section{Seville}

Seville serves as final stopping point in the program prior to returning to Madrid and the United States. The pace of the trip slows to accommodate students and professors alike who have seen much and need time to reflect. Students live with host families and experience what it means to sleep with little or no air conditioning, to sit down for a shared meal at two o'clock in the afternoon and to try tortilla española (a potato omelet) and gazpacho (chilled purée of tomato, garlic, salt and olive oil).

The Cathedral of Seville with its bell tower and giralda (weathervane), looms large as a landmark and testament to the admixture of Islamic and Christian cultures that inhabited the city in the Middle Ages and Early Modern periods. The tower itself served as minaret for the mosque under $\mathrm{Al}$ Andalus and was strategically co-opted as a bell tower for the cathedral by the Catholic conquerors.

Adjacent to the Cathedral and plaza is the Alcazar. As prologue to the group visit to the Alcazar, students read D. Fairchild Ruggles article, "The Alcazar of Seville and Mudejar Architecture" where she queries, "If style has meaning - in the sense of giving physical expression to human values and identity - then what meaning can we ascribe to the adoption of Islamicate forms and motifs by the Christian patron of the Alcazar of Seville in the mid-fourteenth century?" (87). She characterizes well the reciprocal admiration that Peter the Cruel (1334-1369) had for Arab influenced architecture and explains the cultural layers that make up this artistic wonder. At the same time, it is an echo of what students saw in Granada showing the geographic extent of Islamicate influenced structure and design.

The common article readings, student written responses and religious and literary texts assigned drive the morning classroom discussions in Seville, and late afternoons are dedicated to site visits. While classroom time is dedicated to dialogue in small and large groups, afternoon visits are reserved for seeing, for example, the Jewish Barrio Santa Cruz and the former mosque now Iglesia San Salvador. We enjoy partnering with personnel from CEA Seville and a professor from the Universidad Pablo de Olavide who all help arrange site visits, accompany us and offer descriptions about historical significances of places we see.

\section{Identity and Hospitality}

As soon as the study abroad program begins, it seems to come to a close. Part of the nature of Belmont Maymester in Spain is its brevity, but as the second week progresses, as students live in homes with their Spanish hosts, and as they reflect on what they have seen and read, classroom discussions truly begin to take on a different nature. We seize the opportunity to begin raising questions about identity and hospitality in the context of interfaith relations and utilize Barbara Fuchs edition of The Abencerraje read aloud in class to help guide us. Despite the heat of Seville in late May students join in the collective reading exercises and probe each other with inquiries about 
the role of religious traditions, practices, and beliefs in the establishment of individual identity, collective identity, and in hospitality.

\section{Identity}

Both the abstract and the practical aspects of identity were and continue to be crucial to the content of the courses taught and the travel path of the "Belmont in Spain: World Religion and Identities" study abroad program. Though the word identity is frequently used in everyday speech, the intent of this program is to invite students to consider concepts of individual identity, collective identity, and how religion plays an integral role in what is truly a dynamic negotiation - a figuring out who we believe we are and who we are when we interact with others.

A challenging but thoughtful way to generate student reflections is effected by proffering Paul Ricoeur's ruminations on the paradoxes of identity in Reflections on the Just, in which he distinguishes between a narrative identity and a personal identity. Ricoeur's analysis of the narrative identity posits identity against time and he characterizes it under two criteria: its genetic permanence over time and the correlative course of development. "Let us say therefore that a subject capable of leading his or her life in agreement with the idea of narrative coherence is an autonomous subject" (80).

But Ricoeur also focuses upon the personal aspect of identity which he terms "singularity" meaning, "You, and not someone else in your place. The paradox here has to do, not with the temporal dimension, the test of time, but with the confrontation with other perspectives, the test of alterity" (80).

These are fundamentally human capacities, that of narrating our identity and being confronted by the other, that we hope our students will have the opportunity to grasp more profoundly during and after the trip than prior to their study abroad experience. As speculative individuals, all students have some level of self-awareness about their own individual identity with its inherent and cultivated complexities. However, many students have never traveled outside the United States, so their conception of the world and identities of people not born and raised in the United States is limited.

Often their identities as budding adults are strongly influenced by relative insularity. "Belmont in Spain: World Religion and Identities" is often a first opportunity to experience the challenges that being the "other" poses to their achieving practical, felt needs. The language barrier, skeptical askance looks from native Spaniards and the sometimes flippant dismissals inevitably give rise to an array of reactions. These include but are not limited to hurt feelings and complaints about rudeness. They are having to negotiate a new role raised by study abroad - that of being a foreigner.

\section{Hosp itality}

Charles Cosgrove, in his book Appealing to Scripture in Moral Debate, writes that all individuals must make decisions about the moral frameworks by which they choose to live (10). Cosgrove focuses particularly on the tensions that exist within the Judeo-Christian tradition as individuals work with biblical texts that often seem to make competing claims. How might one use canonical texts to guide in the making of a moral decision when the texts appear unclear or even contradictory? 
Considering the idea of hospitality provides a telling example. How to be hospitable to others is a tension that confronts the reader in the text and that also consistently confronts the individual in everyday life. Just as citizens and government officials in the United States work to determine immigration policies today, the writers of the biblical texts faced similar concerns. Depending on their context and particular concerns, the biblical authors offer seemingly disparate answers regarding how to treat the stranger.

For instance, in the books of Ezra and Nehemiah, the reader is confronted with a post-exilic people returning from years of captivity in Babylon. When Cyrus the Great of Persia conquered the Babylonians around $539 \mathrm{BCE}$, he allowed conquered peoples to return to their homelands and offered them some political and religious freedoms. The books of Ezra and Nehemiah provide insight into how the conquered Jewish people attempted to piece their society back together, and part of the construction of that society involved sending away the other. Ezra the priest, in these difficult texts, commands the banishment of foreign wives and their children from community since intermarriage is seen as a stain on the community and repentance is required. The concern for stabilizing a small group of post-exilic people vulnerable to losing their religion and culture because of intermarriage took precedence over hospitality.

In many other biblical texts though, the demand that Jews practice hospitality seems absolute. In Hebrew Bible, narratives about Sodom and Gomorrah and the Levite and his concubine illustrate for the reader that hospitality is not a matter of politeness, but is rather a matter of life and death. Failure to offer the basics of shelter and food to the stranger may result in violence that threatens the very existence not only of the stranger, but also of the Jewish people. By the end of the story of the Levite and his concubine in the book of Judges, one of the twelve tribes of Israel is nearly extinguished, all due to the failure to offer hospitality. And in the New Testament texts, Christians are offered time and again examples from the Gospel narratives that depict Jesus in relationship with the other, those who are not part of acceptable society, the leper, the tax collector, the adulterous woman, and others as well. Most notably, in the parable of the Good Samaritan, Jesus offers the example of a stranger, a foreigner, who offers necessary hospitality to the victim that even the Jewish leadership refuses to give.

It is without question that all of the Abrahamic religions command hospitality, perhaps in different ways and at times in questionable ways, but hospitality is undoubtedly a theme found throughout the sacred texts of Judaism, Christianity and Islam. Studying these faiths in their medieval Iberian and emerging Spanish contexts provides students with an invaluable opportunity to consider how adherents of the three Abrahamic faiths lived together during convivencia. What bound Sephardic Jews, Catholic Christians and Muslims (Umayyad, Almoravid, and Almohad) together in ways that allowed for the production of great art and architecture? What divided these groups to such an extent that religious conversions became forced? What events led to the expulsion of Jews from Spain by King Ferdinand and Queen Isabella in 1492 after the fall of Muslim Granada?

\section{Continuity and Evolution}

After three years of experience with "Belmont in Spain: World Religions and Identities" an opportune moment presents itself for us to evaluate the continuities of the program and consider how the travel, visits, texts and class activities might evolve. 
The books we originally chose by María Rosa Menocal and Barbara Fuchs remain constants in the courses. We added the common articles to show how some historians critique The Ornament of the World as fostering too romantic a notion of convivencia. Contentment with a second text for the Religion and Ethics course has proven more problematic. In 2015, we offered Abraham: A Journey to the Heart of Three Faiths, by Bruce Feiler, but it did not introduce the three faiths to our satisfaction and focused too much on original contexts of the faiths, rather than Spain. In 2016, we substituted Chris Lowney's book, A Vanished World: Muslims, Christians, and Jews in Medieval Spain.

During 2017, we substituted Hagar, Sarah, and Their Children: Jewish, Christian, and Muslim Perspectives, edited by Phyllis Trible and Letty M. Russel instead of Lowney, and there were advantages. It was more readable than Lowney, but where we hoped it would introduce the notion of being free to imaginatively interpret biblical stories like that of Sarah and Hagar students balked. Where they are willing to imaginatively interpret literary texts like The Abencerraje, they are fairly intransigent in reading sacred texts as anything other than sacred.

The imaginative variation in interpreting texts is an ancient practice. Jews were doing this with Midrash centuries ago, but students are resistant to losing the "real" story. We think this can impose unnecessary limits, and blind students to how we constantly change the "real" story depending on our understandings of individual and collective identities. So, we are left with the question of how to move future groups in that direction.

We are quite satisfied with the cities and the places and spaces we see, but not completely convinced that students grasp how contemporary religious practice in Spain plays out. We have taken students to the celebration of mass in Seville's Cathedral, but have also begun discussing the need to add speakers from the contemporary Islamic and Jewish communities.

Belmont Maymester in Spain encourages students to think about religion, its connections to place, the negotiation of identity, and the dynamic ebb and flow of religious faith as we live our lives. Experiences traveling through Spain, seeing countryside, visiting sacred spaces and living with host families create tangible landmarks in the mind that enable students to interpret texts we read and to consider new aspects of identity by evoking those memories. It is the personal interaction with people who are unlike us that requires us to renegotiate our ideas about religion and identity and perhaps moves us closer to becoming the global citizens mentioned by the aspirational goals in Belmont's mission statement. For these reasons, we began offering "Belmont in Spain: World Religions and Identities", and we continue to see possibilities for teaching about religion and identity in future iterations of this short-term study abroad program in Spain.

\section{Works Cited}

"Belmont in Spain.” Belmont U, www.belmont.edu/study/abroad/programs/europe/spain/seville/ index.html. Accessed 16 Oct. 2017.

“Belmont Mission, Vision \& Values.” Belmont U, www.belmont.edu/about/mission.html. Accessed 30 Nov. 2017.

Cosgrove, Charles H. Appealing to Scripture in Moral Debate: Five Hermeneutical Rules. Wm. B. Eerdmans Publishing, 2002.

Charbonneau, Cathy. "Intercultural Appropriation and the Synagogues of Medieval Spain." Journal of Interdisciplinary Research, 2016, www.mospace.umsystem.edu/xmlui/handle/10355/49216. Accessed 15 July 2017. 
Dark, David. Life's Too Short to Pretend You're Not Religious. InterVarsity Press, 2016.

Dodds, Jerrilyn. "The Great Mosque of Cordoba." Al Andalus: The Art of Islamic Spain, edited by Jerrilynn Dodds, Metropolitan Museum of Art, 1992, pp. 11-25.

Feiler, Bruce S. Abraham: A Journey to the Heart of Three Faiths. Perennial, an imprint of Harper Collins Publishers, 2004.

Felton, Anton. Jewish Symbols and Secrets: A Fifteenth-Century Spanish Carpet. Short Run Press Ltd., 2012.

"Foreign Languages and Higher Education: New Structures for a Changed World." MLA, www.mla.org/Resources/Research/Surveys-Reports-and-Other-Documents/Teaching-Enrollmentsand-Programs/Foreign-Languages-and-Higher-Education-New-Structures-for-a-Changed-World. Accessed 30 Nov. 2017.

Fuchs, Barbara, Larissa Brewer-García, and Aaron Ilika. "The Abencerraje” and "Ozmín and Daraja": Two Sixteenth-Century Novellas from Spain. University of Pennsylvania Press, 2014.

Lowney, Chris. A Vanished World: Muslims, Christians, and Jews in Medieval Spain. Oxford U Press, 2005.

Menocal, María Rosa. The Ornament of the World: How Muslims, Jews and Christians Created a Culture of Tolerance in Medieval Spain. Little, Brown and Co., 2002.

"Mission, Vision and Values." Belmont U, www.belmont.edu/about/mission.html. Accessed 16 July 2017.

"NCSSFL-ACTFL Can Do Statements Performance Indicators for Language Learners." 2015 www.actfl.org/sites/default/files/pdfs/Can-Do_Statements_2015.pdf. Accessed 30 Nov. 2017.

“Our History.” Belmont U, www.belmont125.com/history/. Accessed 16 July 2017.

Ray, Jonathan. After Expulsion: 1492 and the Making of Sephardic Jewry. NYU Press, 2013.

Ricoeur, Paul. Reflections on the Just. Translated by David Pellauer, University of Chicago Press, 2007.

Robinson, Marilynne. The Givenness of Things: Essays. Kindle ed., Farrar, Straus and Giroux, 2015.

Rodríguez, Darío Cabanelas. "The Alhambra an Introduction." Al Andalus: The Art of Islamic Spain, edited by Jerrilynn Dodds, Metropolitan Museum of Art, 1992, pp. 127-133.

Ruggles, D. Fairchild. “The Alcazar of Seville and Mudejar Architecture.” GESTA, vol., 43, no.2, 2004, pp. 87-98. JSTOR, doi: 10.2307/25067097. Accessed 19 April 2016.

Soifer, Maya. "Beyond Convivencia: Critical Reflections on the Historiography of Interfaith Relations in Christian Spain.” Journal of Medieval Iberian Studies, vol. 1, no. 1, 2009, pp. 19-35.

Tippett, Krista. "Jaroslav Pelikan - The Need for Creeds." Soundcloud. 24 April 2014, www.soundcloud.com/onbeing/jaroslav-pelikan-the-need-for-creeds.

Trible, Phyllis, and Letty M. Russell. Hagar, Sarah, and Their Children: Jewish, Christian, and Muslim Perspectives. Westminster John Knox Press, 2013.

"Vision, Purpose, Values, Goals." Belmont U, www.belmont.edu/bellcore/vision_purpose_ value_goals.html. Accessed 16 July 2017. 